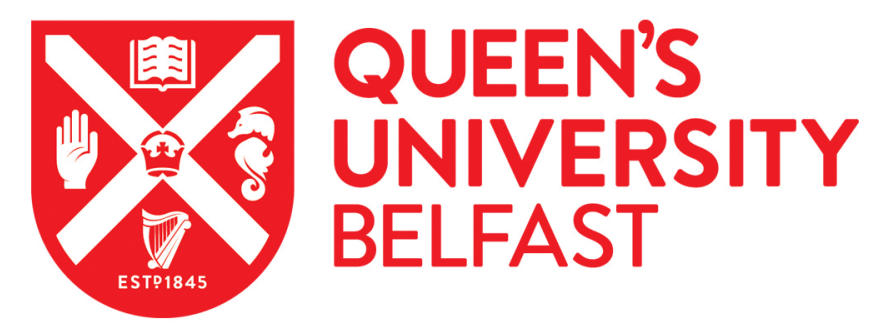

\title{
Desistance from Sexual Offending: Do the Mainstream Theories Apply?
}

McAlinden, A-M., Farmer, M., \& Maruna, S. (2017). Desistance from Sexual Offending: Do the Mainstream Theories Apply? Criminology and Criminal Justice, 17(3), 266-283. https://doi.org/10.1177/1748895816670201

\author{
Published in: \\ Criminology and Criminal Justice
}

Document Version:

Peer reviewed version

Queen's University Belfast - Research Portal:

Link to publication record in Queen's University Belfast Research Portal

Publisher rights

Copyright 2016 The Authors.

\section{General rights}

Copyright for the publications made accessible via the Queen's University Belfast Research Portal is retained by the author(s) and / or other copyright owners and it is a condition of accessing these publications that users recognise and abide by the legal requirements associated with these rights.

Take down policy

The Research Portal is Queen's institutional repository that provides access to Queen's research output. Every effort has been made to ensure that content in the Research Portal does not infringe any person's rights, or applicable UK laws. If you discover content in the Research Portal that you believe breaches copyright or violates any law, please contact openaccess@qub.ac.uk. 


\author{
FINAL AUTHOR VERSION \\ TO BE PUBLISHED IN \\ CRIMINOLOGY \& CRIMINAL JUSTICE
}

\title{
Desistance From Sexual Offending: Do The Mainstream Theories Apply?
}

\author{
Anne-Marie McAlinden* \\ School of Law, Queen's University Belfast, UK \\ Mark Farmer \\ PhD Candidate, Queen's University Belfast, UK
}

\section{Shadd Maruna}

School of Law, University of Manchester, UK

\begin{abstract}
The literature on desistance from crime has become well established in recent years with strong bodies of evidence supporting the role of factors such as employment, relationships and identity change in this process. However, the relevance of this literature to individuals convicted of sexual crimes is not known as such individuals are almost always excluded from this research. This article presents the results from one of the first empirical studies on desistance from sexual offending based on 32 in-depth life story interviews with adult males previously convicted of child sex offences. In this analysis we explore the significance of work, the role of relationships, and changes in imagined selves in the self-identities of individuals successfully desisting from sexual offending. The findings provide support for all three factors in helping to sustain desistance from sex offending, but also suggest clear differences between desistance from sex offending and other types of crime in these regards.
\end{abstract}

\section{Keywords}

Sex offending, desistance, employment, relationships, reintegrative shaming, future selfidentity

\section{Introduction}

Desistance from crime has been the subject of sustained academic attention for the last two decades (e.g. Laub and Sampson, 2001; Kazemian, 2007; Farrall et al, 2014). Indeed,

\footnotetext{
* Corresponding author:

Anne-Marie McAlinden, Professor of Law, Director of Research, School of Law, Queen's University Belfast, University Square, Belfast, BT7 1NN, UK

E-mail: a.mcalinden@qub.ac.uk; Tel: +44 (0)28 90973869
} 
Paternoster and Bushway (2009: 1156) have argued that "theorizing and research about desistance from crime is one of the most exciting, vibrant, and dynamic areas in criminology today." As the study of how and why some individuals with long patterns of offending are able to live crime-free lives, desistance research has obvious implications for those policymakers and practitioners interested in reducing recidivism through ex-prisoner reintegration work (Burnett, 2004; McNeill, 2006; Weaver and McNeill, 2010). In particular, the theory and practice of sex offender treatment in the United Kingdom and elsewhere has been influenced by desistance research in the way that the therapeutic relationship is conceived and delivered (see e.g. Mann, 2004; Ward and Laws, 2010; de Vries Robbé et al, 2015). However, the majority of major research studies in desistance have either explicitly excluded or else implicitly neglected cases of individuals convicted of sexual offending from these analyses. As such, it is unclear whether the theories that have been developed to account for desistance actually apply to the topic of desistance from sex offending or if desistance is an entirely different process for this particular offender group.

In this paper, we join a small but growing literature that seeks to fill this void by exploring the complex interplay between the structural and cognitive processes sustaining desistance from sexual offending from a sample of 32 individuals convicted of sexual offences in England and Wales. As a first step in developing an understanding of desistance from sex offending, this analysis applies the leading "mainstream" theories to the life narratives of our sample to explore how well the theories fit individuals convicted of sexual crimes against children. Specifically, we explore the key themes of "work" and "relationships" as subjectively perceived by individuals formerly convicted of child sexual offences. As two of the key informal social controls thought to underpin desistance from crime (Laub and Sampson, 2001), including sexual offending (Kruttschnitt et al, 2000; Van den Berg et al, 
2014), work and relationships also play a key role in individuals' desisting narratives as part of the process of "reintegrative shaming" (Braithwaite, 1989; McAlinden, 2007). Work and relationships also play a part in the "imagined future selves" (e.g., Giordano et al, 2002; Paternoster and Bushway, 2009) thought to facilitate desistance by the development of an identity that is inconsistent with continued offending (Maruna, 2001).

The article is arranged in four sections. We begin by providing a critical overview of the literature on desistance from sexual crime, before outlining the research methods that were employed for the present study. Following this, the main body of the article examines the themes of work and relationships for the desisting sex offenders within the study. Finally, we discuss the implications of these variables for the future self-identities of individuals deemed to be desisting from sexual crime.

\section{Desistance from Sexual Crime}

While "desistance" can be conceptualised in a number of ways, it is generally taken to refer to the dynamic and often complex process through which individuals who had previously been engaged in patterns of offending refrain from and/or decrease these behaviours over time (Kazemian, 2007). Two related bodies of research have emerged, some exploring social/structural factors that support desistance and the other examining more subjective/cognitive changes related to desistance. In the former, research has focused in particular on the role of stable employment and the formation of intimate relationships (Sampson and Laub, 1993; Savolainen, 2009; Farrall et al, 2014). The latter has focused on changes in self-identity or "future selves" (Giordano et al, 2002; Paternoster and Bushway, 2009). This research demonstrates that the movement away from entrenched patterns of criminal behaviour involves not just external changes of circumstances (jobs, housing, etc), 
but also a fundamental change in a person's self-identity (see e.g. Digard, 2014; Liem \& Richardson, 2014; Soyer, 2014; Rocque et al, 2016). According to this increasingly popular framework, the rehabilitation process involves at some level the need to develop a new story for oneself that can explain one's past and give a convincing account of why the person is no longer like that anymore (Maruna, 2001). Most observers accept that these explanatory factors are complementary and inter-related, with desistance potentially requiring changes in both social/structural and subjective domains (Bottoms et al, 2004; LeBel et al, 2008).

Research on desistance from sexual offending specifically has emerged as a distinct area of study only recently, although concerns with recidivism have a well-established research base. In tandem with broader policy and professional concerns with risk assessment and management (Kemshall and Maguire, 2001), a large body of mainly quantitative research has focused on sexual recidivism (Friendship and Thornton, 2001; Harris and Hanson, 2004) ${ }^{1}$ and the static and dynamic risk factors associated with re-offending (Beech et al, 2002; Heffernan and Ward, 2015). The former are related to historical factors such as age at first offence and history of offending, while the latter pertain to those fluid factors amenable to intervention such as unemployment, or substance misuse, and are thus of more relevance for discourses on desistance. This body of research suggests that the risk of re-offending reduces over time and declines with age and that sexual recidivism rates are lowered when treatment and tailored social supports are available (Scoones et al, 2012). Although the age-crime curve peaks and tails off less dramatically for sex offending than it does for non-sexual forms of crime (see Glueck \& Glueck, 1937; Sampson and Laub, 2003; Bottoms et al, 2004), sex offending also appears to decrease with age (Lussier et al, 2010). In short, research has undermined the

\footnotetext{
${ }^{1}$ Whilst some studies suggest higher rates of recidivism for sex offenders, Harris and Hanson's (2004) metaanalysis of over 4,500 sexual offenders found an average long-term re-offending rate of 24 per cent over 15 years and that the longer offenders remained offence-free in the community the less likely they are to reoffend sexually.
} 
popular perception that risk levels associated with sex offending are "high, stable and linear" (Lussier et al, 2010: 147) by demonstrating that recidivism rates for these types of crime are generally low in comparison to other classes of offending (Harris and Hanson, 2004; Barnett et al, 2010).

Therefore, most people who have committed sexual offences appear to desist from sexual offending at some point in their lives, yet little is known about how this process works. As Harris (2014: 1555) has argued "[w]ithout labeling it so, the empirical reality of low sexual recidivism is essentially evidence of desistance." However, while there is some work on the onset, causes and longevity of sexual offending (Seto, 2008; Wortley and Smallbone, 2014), particularly within the context of young people who display harmful sexual behaviour (Hackett et al, 2013), the dynamic nature of sex offending and how and why this process of desistance from sexual crime might occur has largely been a neglected dimension of the criminological endeavour.

A small number of recent studies have attempted to examine sexual offending within the rubric of desistance or reintegration (e.g. Willis et al, 2010; Farmer et al, 2012; Göbbels et al, 2012). Most of this work has been either theoretical (McAlinden, 2007; Laws and Ward, 2011) or else exploratory in nature with small sample sizes (e.g. Farmer et al, 2012; Kewley et al, 2016), but a portrait of how desistance works for this population is starting to emerge. Kruttschnitt et al (2000), for example, in their large-scale study of 556 individuals convicted of sexual offences found that job stability significantly reduced the probability of reoffending, but that marital status had no significant effect on desistance (see also Schaeffer $e t$ al, 2004; Van den Berg et al, 2014). Although the authors did not explore more subjective or cognitive changes associated with desistance, Harris' (2014) qualitative investigation of 
desistance among a group of 21 adult males convicted of sexual offences identified a continuum of cognitive transformations, ranging from a simple recognition that the individual has caused harm through to the creation of a new, non-offending identity (see also Farmer et al, 2012; Kewley et al, 2016).

\section{Methods}

The aim of the present study was to contribute to this emergent field of research by examining the core themes arising from the self-narratives of a sample of men convicted of sexual offences against children. Consistent with much of the recent research on desistance from crime (see e.g., Carlsson, 2012; King, 2013a; Liem and Richardson, 2014), this study focuses on the "internal narrative of desistance" (Vaughan, 2007) in order to better understand the role that employment, relationships and future selves play in the cognitive mindset that supports ongoing desistance from sexual crime. A total of 32 individuals were interviewed, all of whom had at least one conviction for a sexual offence against a child and who had been or were currently under the supervision of the probation service in England and Wales.

This research employed a purposive sampling strategy in an effort to identify two contrasting groups: individuals who were actively desisting from sexual offending and a comparison group of individuals who were closer to the time of their offending, and so could not yet be deemed to be fully "desisting." Operationalising concepts such as "desistance" in the context of sexual crime remains one of the most contentious aspects of this type of research (see Kazemian, 2007; Laws and Ward, 2011). It is not possible to reliably determine whether an individual is desisting or not based on official convictions alone, and self-reports for this type of offence are notably unreliable (Weinrott and Saylor, 1991). However, time since the last 
conviction is a useful proxy measure; previous research (e.g. Hanson et al 2014) has shown that expected sexual recidivism rates approximately halve after 5 years, and halve again after 10 years. It is possible that individuals may have committed crimes that have not been detected, but recent enhancements in the multi-agency management of sexual offending (Kemshall and Maguire, 2001) means that a substantial amount of hidden offending is unlikely. Still, although desistance for non-sexual offences has often been operationalized by periods of crime-free behaviour as short as 12 months to 2 years (e.g. Healy, 2010), it is generally agreed that patterns of sex offending require a longer follow-up period to detect "true" desistance due to the differing nature of the crimes and the substantial "dark figure" of undetected sex crimes (Hanson, 2002).

For the purposes of this study, we operationalised our "desisting" group as follows: Individuals who had previously been convicted of sexual offences against children ${ }^{2}$, who had been living in the community for at least 5 years, during which time there were no new charges or investigations for sexual offending. ${ }^{3}$ Our comparison sample consisted of individuals who had received convictions for child sex offending on more than one occasion ${ }^{4}$, the most recent of which was for an offence within 12 months from the date of the research (fieldwork conducted July 2013-April 2014). For this group the recent nature of their repeat offending suggests that they could not be said to be in a stable state of desistance at the point

\footnotetext{
${ }^{2}$ All 'desisting' participants had been convicted on only one occasion, but in many cases this conviction was a result of a pattern of behavior, almost always against a single victim, lasting between a matter of weeks up to some years.

3 The time "at-risk" did not include time spent in prison, so where an individual had spent time in prison this was deducted from the time "at-risk." When the research began we struggled to identify suitable candidates for this group so the 5-year rule was initially relaxed to 3 years. Consequently a number of participants with fewer than 5 crime free years were interviewed before a more reliable means of identifying those who had been crime-free for longer periods was found.

${ }^{4}$ The number of convictions was deemed to be a useful factor since research suggests that individuals with just one previous conviction are significantly less likely to re-offend than those with two or more previous convictions (Harris and Hanson, 2004). It proved very difficult to identify individuals for the comparison group, and not all participants fully met the criteria we set in this category.
} 
at which they were interviewed. A total of 25 individuals in the desisting group and 7 in the comparison group were interviewed. The latter group is obviously too small on which to base firm conclusions about sexual offending and was intended primarily as a comparator group.

Table 1 presents further details of the sample. Participants ranged in age from 20-29 to 70-80 years and had committed a range of both contact and non-contact offences against children of both genders, which included indecent exposure, engaging in sexual activity in the presence of a child and rape. The average number of years since the last known offence was 11 years and 1.5 years respectively for the desisting and comparison groups. Where known, the modal categorisation of re-offending risk was "medium risk".5 Bottoms et al (2004: 372) refer to this as "programmed potential." As they caution, however, such risk assessments are statistical tools based on analysis of groups with similar characteristics and are of limited value in predicting individual behaviour. Despite one's risk category, individuals frequently "buck the trend" (Bottoms et al, 2004: 372) and the study of desistance is largely the study of "false positives" (Maruna, 2001) or success among those predicted to fail. The value of such assessments in investigating individual desistance is therefore limited especially as recidivism rates for sexual offenders are low in any event (Barnett et al, 2010).

The semi-structured interview protocol was based on a modified version of McAdams' $(1993,2006)$. Life Story Interview. Interviews lasted between 1 and 2 hours and took place in 2013 and 2014. Following a grounded, inductive methodology, initial coding to broad themes was followed by more

\footnotetext{
${ }^{5}$ Data was available, at the time of interview, for some but not all participants (13 group A participants (41\%) and 3 group B participants (43\%)). The risk assessments were as assessed by the probation service using either RM2000 or OASys. The risk assessments, referring to the likelihood of reconviction were either based on static (historical) risk factors such as age or previous criminal history, or dynamic risk factors such as attitudes, or a combination of both. It should be noted that the probation service routinely assesses risk for all those convicted of sexual offences, but those assessments were not, in all cases, available for this research.
} 
detailed, focused coding and analysis (Charmaz 2006). ${ }^{6}$ The analysis of life story data in understanding criminal careers draws together elements of personality psychology and sociology within a rubric that has become known as "narrative criminology" (Presser and Sandberg 2015). Narrative criminology is based on the notion that people make sense of their lives by constructing them temporally in sequences which can be broadly understood as "stories" (McAdams 2006) and that these stories form the basis of a person's self-identity. This framework suggests that by understanding the "stories that people live by," social scientists can better understand patterns of behaviour such as desistance from offending from the person's perspective (see e.g. Maruna, 2001; King, 2013a; Liem and Richardson, 2014; Soyer, 2014). Data analysis followed this phenomenological approach (e.g. Smith et al, 2009), seeking to understand and interpret the meanings research participants place upon their lives and their position in the world.

\section{Findings}

The excerpts used below are representative of the sample as a whole. Interviewees are differentiated by an interview number and letter: A for putatively desisting interviewees and B for the small group of individuals deemed to be closer to the point of their offending, who had not yet formed a stable pattern of desistance. Identifying information has been changed or removed from the quoted material and excerpts are kept short to prevent identification.

\section{Work Identities}

Existing research on desistance from non-sexual offending has consistently highlighted the significance of work to a person's identity in the early stages of desistance (Sampson and Laub, 1993; May, 1999). The intrinsic benefits of employment as a vehicle for desistance are said to derive from new forms of "routine activities" (Cohen and Felson, 1979), informal social controls, social stability and support and the possibility of meeting role models who are

\footnotetext{
${ }^{6}$ For a detailed discussion see Farmer et al (2015).
} 
not involved in an offending or criminogenic lifestyle. Moreover, while desistance is now commonly understood as a progressive, and often reiterative or intermittent process rather than a specific, isolated event (Maruna, 2001; Carlsson, 2012), work has also been shown to act as a "turning point" in the lives of individuals (Sampson and Laub, 1993; Uggen, 2000). In this sense, the benefits of work are thought to derive from the provision of "pro-social" opportunities (Burnett and Maruna, 2006) as well as the development of "human capital" (McNeill et al, 2012). Additionally, work is said to provide meaning to individual lives and give individuals a vested interest in having "something to lose" through getting in trouble with the authorities again (Laub \& Sampson, 2001).

Consistent with this general desistance literature, having a career unquestionably seemed to be of central importance within the identity narratives collected as part of this study. Some had managed to build successful careers from which they gained considerable personal satisfaction and financial reward, whereas others had had a series of jobs over the life course. Many of the desisting sample described gaining some particular stage of employment as a "high point" in their lives, and several defined themselves almost exclusively in terms of their work lives. Typical responses included: "Work ... was a foundation and it's still a foundation to my life, my whole life" [A1] and "I live for work and work lives for me" (A2).

For many of the sample participants, work was related to "having a purpose" and clear life goals. Several of the interviewees deemed to be desisting, for example, commented that "I've always been a grafter ... I love my work ... It keeps me very busy, it gives me a lot of pleasure and the end product when I know it's been good then I suppose it gives me quite a buzz" (A3); and "work will give you something to get up in the morning for" (A1). Others related this purpose explicitly to financial and family stability: “[It was] all about money 
because I had a family" (A4); "[I had] 3 children and ... I was happy because I felt I was able to provide for them and that was a good feeling" (A5). Beyond job satisfaction others mentioned the social aspects of work and opportunities for advancement in terms of "getting an experience, getting friendships, socialising with people, you go into a workforce and you're there for about 6 months to a year, you've probably built up relationships" (A6).

One common sub-theme was the self-awareness of the importance of "keeping busy" or remaining occupied as a situational coping mechanism. This seemed to be particularly the case for men who had offended over the internet in the past. This sub-group of interviewees expressed awareness that if they were sitting at home unoccupied there would be a temptation to engage in inappropriate activities: "I won't sit down and do nothing, I have to be doing something ... because I want to be kept busy, I don't want time ... I enjoy work" (A2); "Because you keep out of trouble then ... If you're working you keep out of trouble, you keep yourself occupied" (A7). When asked "what happens when you get bored?" the interviewee replied: "You make convictions then don't you" (A7). Such responses support the situational/opportunity-based nature of sexual offending in their lives or self-concepts (see generally Wortley and Smallbone, 2006). At a more basic level, however, this self-awareness of the risks of idleness may operate as a facilitator of desistance.

Overall, almost all of the desisting men in the study wished to be seen as active people, wanting to engage in a lifetime of work. In this sense, the putative desisting narratives can be contrasted somewhat with those of interviewees who had not yet established a pattern of desistance, some of whose life histories lacked clear purpose and direction related to work: "I tried many things ... I think I just sort of like drifted through life for a bit" (B1) and where for some there was a discernible frustration and despondency with their employment station: 
I had more brains than my boss did, it was like what am I doing this stuff for when I could be doing their job? ... I would work at a place as long as I was learning, as soon as ... I felt I was in the same place doing the same job every day, not progressing in anyway, I was gone. ... Up to that age [mid-20s] I had probably had over a hundred different jobs, I trained in numerous, numerous jobs (B2).

Acknowledging the fact that work was seemingly important to all of the men in the study, and accepting the modest size of the comparison sample, this subtle difference between the two groups in the nature of their attitude towards work seems to support the idea that personal fulfilment gained from work is an important component of desistance for sex offenders as it is with other types of crime (see also Kruttschnitt et al, 2000; Schaefer et al, 2004).

On the other hand, in contrast to the wider literature on desistance, for interviewees in this sample gaining employment did not appear to be directly related to a "shift" in their identity or a turning point away from crime. First, most of the men said that they had already experienced stable and potentially rewarding careers prior to and during their sexual offending. Second, several described desisting from further criminal activity despite losing their jobs as part of their convictions. Third, the comparison sample in our study also described the important role that employment played in the shaping of their future selfidentities as well. Although several described a sense of frustration with work and of "drifting through life", a minority also prized work as part of their aspirations about the future.

Consistent with the literature (Brown et al, 2007; McAlinden, 2009), interviewees in both groups reported the difficulties they had in obtaining work following their conviction for sexual offences against children: "the constant "No's"' (A8) and the feeling that "they mark you down and nobody's going to employ you with that sort of crime" (A4). While a minority of interviewees reported support from their employers who, in the words of one desisting 
participant, "backed me and even to now, they're still backing me" (A2), many interviewees reported how employers would reject them when they learned of their conviction, and some had resigned themselves to the assumption that they would never work again: "I ended up losing my job because of my offence again ... and that kind of put me back to square one" (A8); "That gets me depressed sometimes ... I can't see me overcoming the work one" (A4) and "I could have applied for some jobs but what they're offering isn't worth coming off unemployment benefits" (B3). However, some men described quite innovative forms of selfemployment which they had devised in order to compensate for not being able to obtain formal work (e.g. painting and decorating, gardening, and a courier service).

Moreover, for those in the desisting sample in particular, the interviewees were insistent that these setbacks at work were unrelated to the likelihood that they would continue offending. Therefore, although we found that work careers were central to the self-identities of the interviewees in our study and offered a positive sense of self, consistent with previous research (e.g. Schaefer et al, 2004), the connection between this work identity and desistance from sexual crime is not immediately clear. In particular, successful desistance does not appear to be linked to new career opportunities in the form of a clear turning point away from crime in the self-narratives of our participants.

\section{Relationships and Reintegrative Shaming}

A related body of desistance research suggests that forming new and meaningful relationships can provide individuals with the emotional and social capital they need to sustain a crime free life (Laub et al, 1998; Niven and Stewart, 2003). The factors underpinning the importance of relationships are thought to be similar to those described above for work as the other half of what has been termed the "respectability package" (Giordano et al, 2002) - relationships give 
people a sense of meaning in their lives, and an emotional investment that they do not wish to lose. New relationships can also disrupt routine activities that may have brought people into situations where crime was likely (Warr, 1998), and provide a form of informal social control where the risk of losing a valued intimate relationship acts as a primary motivator for conformity and a check on future criminal behaviour.

Consistent with this wider literature, relationships featured heavily in the narrative identities of the research participants in this study. Most of the desisting sample described lengthy relationship histories, which clearly had great significance for their sense of self. For many of the interviewees, marriage or meeting their partner, having children and, to a lesser extent, friendships in their childhood or adolescence were deemed to be "high points" in their lives. Conversely, the loss of intimate relationships, divorce or relationship breakdown or the deaths of a parent/grandparent were deemed to be "low points." Similarly, for those interviewees who were parents, the loss of contact with their children due to their convictions for sexual offending was also deemed by some participants to be the lowest ebb in their life course: "I went from having loads of friends to no friends ... So it affected me a lot because I lost everybody" (A8); "I've spoilt a good family unit that was really working. I was happy in there and I miss my ... boys ... and I can't see them until they're $18 \ldots$ That's the biggest regret, spoiling the family" (A9).

Indeed, for a minority of interviewees the circumstances surrounding the conviction for sexual offending seemed to occur at a low point in their personal lives where they were feeling marginalised or emotionally isolated in the aftermath of a relationship breakdown: there were "a lot of roller coasters going on" (A10); "my girlfriend split up with me and I felt 
lonely again and ... I was feeling quite low so yeah I think that's why I started again” (B1).

One desisting interviewee recounted:

It was at this period of time that I committed the offence ... there was a lot of problems ... I felt as if I was left out, I didn't feel any love and arguments had been building up ... obviously I offended ... there's no doubt about that ... but I wanted basically, I was looking for someone to emotionally cheat with (A11).

However, again, the relevance of these relationship histories for desistance was ambiguous and the chronology of relationship beginnings and endings was generally not consistent with the notion of marriages acting as a turning point leading to reform. In fact, the narrative of "settling down" into a relationship as a means of transitioning out of a pattern of criminal involvement was largely absent from the interviews, although two participants did attribute the start of their desistance to relationships: one, who argued he had less contact with his victims due to forming a new adult relationship; and the other, who noted improving relationships with an existing partner that made his offending less relevant. Aside from this, as noted below, many described lengthy relationships histories which had preceded the offending where their partner had "stood by them." There may be a number of plausible reasons for this. For one, unlike some non-sexual forms of crime (Warr, 2002), sex offences are typically not committed in networks or gangs (Grubin, 1998) (those convicted of organised types of child sexual exploitation were not present in the study group), therefore the notion that severing links with criminogenic networks assists desistance was simply not relevant for most of the sample. Furthermore, the commission of a sexual offence and subsequent detection for some interviewees resulted in the ending of relationships, particularly where children were involved, a pattern that was consistent for both sample groups. 
At the same time, desistance narratives were certainly strongly characterised by themes of forgiveness and the importance of social support throughout extraordinarily difficult circumstances: "A lot of people [have] ... supported me from day one ... my main friends have stuck with me ... And that was a big boost for me" (A10); "If I didn't have support I don't know where I'd be" (A4); "To get that reaction after you've told them what you've done it kind of makes you think people are on your side" (A6); and "They've never turned their back on me. They've always been completely supportive of me" (B2).

For a small number of interviewees, the love of a partner acted as a key preventative measure against an escalation of offending: "I thought I've been a fool, I could've lost her, you know, if anything had have happened, if it had of gone further, I could have lost her after all this time. And that brought me to my senses" (A12). Another research participant also expressed the importance of relationships in his life in terms of fear of losing them:

Living on my own, ... and having nothing, I'd be some sad lonely drunken bedsit-living man who don't see his kids ... that would be my worst nightmare ... some other man sat in my chair, in my house, with my wife and my kids (A13).

This also accords with Paternoster and Bushway's (2009) finding that early stage desistance, is triggered initially by the realization of possible negative outcomes associated with criminality including the breakdown of intimate relationships.

Within this broader context, several participants were also concerned with the impact of their offending, and the stigma and suffering associated with it, on their family, principally their wife or partner: “My wife, she was spat on in the street, they were blaming her, it wasn't her fault ... me doing the offence wasn't her fault. It was my weakness" (A14); and "I feel sorry for my wife because even though I know our marriage was probably drifting apart, I should not have done that to her ... she's had to take the embarrassment of it all" (B1). For the 
desisting group, in particular, regret about the past was typically combined with optimism about the future: "That was a very stressful and hard time for my whole family but we've got through it and ... come out a lot stronger" (A2).

Finally, for some of this group, the intrinsic value and importance of relationships in their lives was framed in terms of a more positive "redemptive" narrative (Maruna, 2001): "That means a lot to me. I mean, my partner's support is the main one. She knows, she says she knows the person now, not the person then" (A15). Overall, the role of relationships in the self-narratives of our sample, therefore, accorded more with Braithwaite's (1989) notion of "reintegrative shaming" - a theory which has thus far been applied to sex crimes primarily on a theoretical basis (see McAlinden, 2007). Indeed, within the self-understandings of the desisting interviewees, two key correlates of this theory clearly emerged (see (Braithwaite, 1989: 84-85). One was the role of "significant others" in the process of reintegration and desistance:

I love my wife to bits, I really do, I just feel so ashamed that I might've upset her and lost her for the offence I did but now we've got to so much positive outlook and the future to live, put the past behind us (A12).

The other was the need to break from the sex offender label by actively shaming the sexual offending behaviour rather than the individual themselves:

I got a fiancée, she knows what wrongs I've done in my life but she doesn't look at that, she looks at me as an individual, me as what I am now ... and the person I am ... she says ... in relation to the offence, it was a blip, it was something that shouldn't have happened, it was a junction, wrong turned and I turned the junction and came back on track again, and that's the way ... my partner looks at it, you know, and that's the way that is (A16).

This capacity to embrace a new non-criminal identity and to move on from the legacy of an offending past or to "put the past behind them" was integral to the desisting narratives of the participants in the present study. 


\section{Discussion: Imagined and Actualised "Future Selves"}

Although desistance from crime has become an established and even prominent topic within criminology, desistance from sexual crime is only beginning to emerge as a distinct area of study. Overall, our findings provide support for an "integrated" theory of desistance from sexual offending (Farrall et al, 2011) involving both structural/social processes as well as the internal subjective changes. A century ago, Freud (2010: 68) argued that "the compulsion to work" and "the power of love" were the cornerstones of humanity and the two essential ingredients of a well-adjusted personality. Indeed, the narratives of the desisting participants in this study were replete with references to both work and relationships as being central to their non-offending identities. However, the linear and often precipitous association between these variables and a new non-criminal identity, which features within the general literature on desistance, was not manifested as clearly.

Rather, desistance from sexual offending emerged as an alternative identity in which relationships and work in particular appeared key to the formulation of a new future self (notably absent from the narratives of almost all of the offenders deemed as not having yet established a clear pattern of desistance). Within the broader desistance paradigm of cognitive transformations and agency, a key theme is the importance of the reflective self and the ability to "imagine" a plausible new personal identity (Maruna, 2001; Paternoster and Bushway, 2009; Healy, 2014), or what Giordano et al (2002: 1001) have termed a "replacement self." Work and relationships are thought to be central to this process with the pro-social roles and identities they provide; however, this is a broader concept involving the person's "ability to imagine a valued new identity" (Healy, 2014: 873) and the internalised hope and self-efficacy necessary to achieve these goals (Burnett and Maruna, 2004; Dickson and Polaschek, 2014). As Vaughan has argued, this kind of "self-reflexivity" is often 
achieved "through an internal moral conversation that is often couched in terms of agents' ultimate concerns and their relationship with others" (2007: 390). A desired non-criminal identity, however, does not always accord with the reality of lived experience in that some individuals do lapse into criminal activity (Shapland and Bottoms, 2011; Soyer, 2014). The core task, therefore, becomes one of being able to discern what factors are likely to underpin this kind of transition in identity.

In this sense, nearly all of the desisting group participants in the study portrayed themselves as being in control of their lives and had a clear sense of purpose and planning for the future. These future aspirations often related to finding or sustaining stable employment and maintaining existing or building new relationships. Consistent with the notion of "the credible imagined self" (Healy, 2014: 873), most of these ambitions appeared consistent with the individual's abilities and social capital. In terms of relationships, many of the desisting interviewees couched their future desires in terms of "building more adult relationships" (A7); or "a nice steady relationship, I think that's the most important one" (A4). For others, the familial relationship singled out of most importance to them was in terms of the parentchild relationship:

At this point in my life, I see it like there's a ray of light, I'm not going to let this whole thing ... what's happened, drag me down ... that's what I want in life, is for my daughter, for me, for my family, just to be happy (A11).

Similarly in relation to work, when asked where they saw themselves in five years' time many of the desisting interviewees spoke of their future aspirations in terms of work: "just in a job where I'm earning money and getting experience and hopefully kind of in an opportunity, moving up the ladder" (A6); "I'd like a little part time job I would" (A7). In this sense it is perhaps most illustrative of this theme to contrast the views about the future held 
by a desisting interviewee and another who was deemed to be not yet in a stable pattern of desistance:

In the future I hope to be happy, erm, offence free ... I would like to eventually get into a relationship ...I'd just like to be happy with good friends around me, family, good job (A18).

It's probably because I've got older ... I feel old, all I want to do is just sit, watch a bit of TV, do a bit of cooking, I have no desires to go out and jump into relationships which is what's been talked about in the past and I don't want to do any of that crap anymore (B3).

Of note is the fact that all of the desisting participants appeared to have formulated clear and tangible goals for the future and envisioned a new plausible sense of self. Consistent with Healy's (2014) finding with non-sexual offenders, there were discernible differences, however, in terms of perceived barriers to achieving these goals and how attainable they deemed their future self to be. These related in particular to forming new relationships, barriers to employment opportunities, and fears related to both of these variables surrounding the decision to self-disclose their offending past.

Furthermore, the fact that the desisting narratives evidenced a concern with the impact of their sex offending behaviour and the social stigma associated with it on their families and partners lends empirical support to the reintegrative potential of significant relationships (Braithwate, 1989; McAlinden, 2007). While Braithwaite's framework was originally conceived as applying to socio-penal processes, it has also emerged here as being of relevance for the personal-psychological processes underpinning reintegration and desistance, specifically the role of families and relationships as protective factors. This emergent theme is one we intend to develop further in subsequent papers. 
Research has demonstrated that the process of identity reconstruction begins in the primary or early stages of desistance (King, 2013a). Secondary or longer term desistance has been defined by Maruna and colleagues as "the assumption of the role or identity of a "changed person"” (2004: 274). This fundamental transition in identity from offender to non-offender, requires not just the ethereal imagining of a new self and the aspirational commitment to prosocial goals but the corporeal realization of this new self through the active commitment to conventional pro-social roles (Serin and Lloyd, 2009; Healy, 2014). This study has demonstrated the significance of two such pro-social aspects - work and relationships - in the formulation of desisting identities for a sample of men previously convicted of sexual offences against children.

From a policy perspective, the major implications of this research involve bridging this gap between what has variously been termed "imagined" (Soyer, 2014) and "authentic" desistance (Healy, 2014) for sex offenders and in overcoming the social context which may hinder desistance trajectories by "delimit[ing] the range of future possibilities" (King, 2013b: 317; see also Serin and Lloyd, 2009). Successful community re-entry and social reintegration is a key step on the path to desistance from sexual offending (Göbbels, et al, 2012; Lussier and Gress, 2014). There is a need, therefore, to develop "a dialogue" between desistance research and public protection frameworks which reflect the discourses of both "control" and "change" (Weaver, 2014), with in-built capacities for expanding the pro-social self identities of sex offenders. Put simply, the agentic willingness to change on the part of individuals like those in this sample needs to be accompanied by credible social opportunities for change and a range of external situational supports to help sex offenders achieve meaningful lives. 
Table 1: Further Details of the Sample

\begin{tabular}{|c|c|c|c|}
\hline & & $\begin{array}{l}\text { 'A' } \\
\text { Participants } \\
(n=25)\end{array}$ & $\begin{array}{l}\text { 'B' } \\
\text { Participants } \\
(\mathbf{n}=7)\end{array}$ \\
\hline \multirow[t]{7}{*}{ Age range at time of interview } & $20-29$ & 3 & 2 \\
\hline & $30-39$ & 2 & \\
\hline & $40-49$ & 7 & 1 \\
\hline & $50-59$ & 3 & \\
\hline & $60-69$ & 5 & 2 \\
\hline & $70-80$ & 5 & \\
\hline & unknown & & 2 \\
\hline \multirow{2}{*}{$\begin{array}{l}\text { Sexual offence type ( some participants were convicted } \\
\text { of more than one sexual offence hence total number of } \\
\text { offences is greater than total number of participants) }\end{array}$} & Contact & 17 & 4 \\
\hline & Non-contact & 9 & 5 \\
\hline \multirow{3}{*}{$\begin{array}{l}\text { Gender of victim (some participants committed offences } \\
\text { against children of more than one gender) }\end{array}$} & Male & 5 & 0 \\
\hline & Female & 18 & 4 \\
\hline & Unknown & 4 & 3 \\
\hline \multicolumn{2}{|l|}{ Average no of years since last known offence } & 11 & 1.5 \\
\hline
\end{tabular}




\section{Note}

This work was supported by the Economic and Social Research Council [grant number ES/K006061/1]. The research data and materials cannot be made open access due to access agreements and the sensitivity of the data.

\section{References}

Barnett, G.D., Wakeling, H.C., and Howard, P.D. (2010), 'An Examination of the Predictive Validity of the Risk Matrix 2000 in England and Wales', Sexual Abuse: A Journal of Research and Treatment 22(4): 443-470.

Beech, A., Friendship, C., Erikson, M., and Hanson, R. K. (2002), 'The Relationship between Static and Dynamic Risk Factors and Reconviction in a Sample of UK Child Abusers', Sexual Abuse: A Journal of Research and Treatment 14(2):155-167.

Bottoms, A., Shapland, J., Costello, A., Holmes, D. and Muir, G. (2004), 'Towards Desistance: Theoretical Underpinnings for an Empirical Study', The Howard Journal 43(4): 368-389.

Braithwaite, J. (1989), Crime, Shame and Reintegration (Sydney: Cambridge University Press).

Brown, K., Spencer, J. and Deakin, J. (2007), 'The Reintegration of Sex Offenders: Barriers and Opportunities for Employment', The Howard Journal 46(1): 32-42.

Burnett, R. (2004), 'One-to-one ways of Promoting Desistance: In Search of an Evidence Base', in R. Burnett R and C. Roberts (eds), What Works in Probation and Youth Justice: Developing Evidence-based Practice (Cullompton: Willan). 
Burnett, R. and Maruna, S. (2004), 'So "Prison Works", Does It? The Criminal Careers of 130 Men Released from Prison under Home Secretary, Michael Howard', The Howard Journal of Criminal Justice 43(4): 390-404.

-- (2006), 'The Kindness of Prisoners: Strengths-based Resettlement in Theory and in Action', Criminology \& Criminal Justice 6(1): 83-106.

Carlsson, C. (2012), "Using "Turning Points" to Understand Processes of Change in Offending Notes from a Swedish Study on Life Courses and Crime' British Journal of Criminology 52(1): 1-16.

Charmaz, K. (2006), Constructing Grounded Theory: A Practical Guide Through Qualitative Analysis (London: Sage Publications).

Cohen, L.E. and Felson, M. (1979), 'Social Change and Crime Rate Trends: A Routine Activity Approach', American Sociological Review 44(4): 588-608.

de Vries Robbé, M., Mann, R. E., Maruna, S. and Thornton, D. (2015), ‘An Exploration of Protective Factors Supporting Desistance from Sexual Offending', Sexual Abuse: A Journal of Research and Treatment 27(1): 16-33.

Dickson, S.R., and Polaschek, D.L. (2014), 'Planning to Avoid Risk or Planning for a Positive Life The Relationship Between Release Plan Valence and Reoffending', International Journal of Offender Therapy and Comparative Criminology 58(12): 1431-1448.

Digard, L. (2014), 'Encoding Risk: Probation Work and Sex Offenders' Narrative Identities', Punishment \& Society 16(4): 428-447.

Farmer, M., Beech, A.R. and Ward, T. (2012), 'Assessing Desistance in Child Molesters: A Qualitative Analysis' Journal of Interpersonal Violence 27(5): 930-950. 
Farmer, M., McAlinden, A.-M. and Maruna, S. (2015), 'Understanding Desistance from Sexual Offending:A Thematic Review of Research Findings', Probation Journal 62(4): 320-35.

Farrall, S., Hunter, B., Sharpe, G. and Calverley, A. (2014), Criminal Careers in Transition: The Social Context of Desistance from Crime (Oxford: Oxford University Press).

Farrall, S., Sharpe, G., Hunter, B., and Calverley, A. (2011), 'Theorizing Structural and Individual-level Processes in Desistance and Persistence: Outlining an Integrated Perspective' Australian \& New Zealand Journal of Criminology 44(2): 218-234.

Freud, S. (2010), Civilization and Its Discontents, first published in German in 1930 (Mansfield Centre, CT: Martino Publishing).

Friendship, C. and Thornton, D. (2001), 'Sexual Reconviction for Sexual Offenders Discharged From Prison in England and Wales: Implications for Evaluating Treatment', British Society of Criminology 41(2): 285-92.

Giordano, P.C., Cernkovich, S.A., and Rudolph, J L. (2002), 'Gender, Crime, and Desistance: Toward a Theory of Cognitive Transformation', American Journal of Sociology 107(4): 990-1064.

Glueck, S. and Glueck, E. (1937), Later Criminal Careers. New York: Kraus.

Göbbels, S., Ward, T. and Willis, G.M. (2012), 'An Integrative Theory of Desistance from Sex Offending' Aggression and Violent Behavior 17(5): 453-462.

Grubin, D. (1998), Sex Offending Against Children: Understanding the Risk, Police Research Series Paper No. 99 (London: Home Office).

Hackett, S., Phillips, J., Masson, H. and Balfe, M. (2013), 'Individual, Family and Abuse Characteristics of 700 British Child and Adolescent Sexual Abusers', Child Abuse Review 22(4): 232-245. 
Hanson, R.K. (2002), 'Recidivism and Age: Follow-up Sata from 4,673 Sexual Offenders', Journal of Interpersonal violence 17(10): 1046-1062.

Hanson, R.K., Harris, A.J.R., Helmus, L. and Thornton, D. (2014), 'High-Risk Sex Offenders May Not Be High Risk Forever’ Journal of Interpersonal Violence 29(15): 2792-2813.

Harris, A.J.R. and Hanson, R.K. (2004), Sex Offender Recidivism: A Simple Question (Canada: Public Safety and Emergency Preparedness Canada).

Harris, D.A. (2014), 'Desistance from Sexual Offending: Findings from 21 Life History Narratives', Journal of Interpersonal Violence,29(9): 1554-1578.

Healy, D. (2010), The Dynamics of Desistance: Charting Pathways through Change (Cullumpton: Willan Publishing).

-- (2014), 'Becoming a Desister Exploring the Role of Agency, Coping and Imagination in the Construction of a New Self', British Journal of Criminology 54(5): 873-891.

Heffernan, R., and Ward, T. (2015), 'The Conceptualization of Dynamic Risk Factors in Child Sex Offenders: An Agency Model', Aggression and Violent Behavior 24: 250260.

Kazemian, L. (2007), 'Desistance from Crime: Theoretical, Empirical, Methodological, and Policy Considerations', Journal of Contemporary Criminal Justice 23(1): 5-27.

Kemshall, H. and Maguire, M. (2001), 'Public Protection, Partnership and Risk Penalty: The Multi-agency Risk Management of Sexual and Violent Offenders', Punishment and Society 3(2): 237-64.

Kewley, S., Larkin, M., Harkins, L., and Beech, A.R. (2016), 'Restoring Identity: The Use of Religion as a Mechanism to Transition between an Identity of Sexual Offending to a Non-offending Identity', Criminology and Criminal Justice, OnlineFirst, doi: $10.1177 / 1748895816654530$. 
King, S. (2013a), 'Early Desistance Narratives: A Qualitative Analysis of Probationers' Transitions towards Desistance', Punishment \& Society 15(2): 147-165.

King, S. (2013b), 'Transformative Agency and Desistance from Crime', Criminology and Criminal Justice 13(3): 317-335.

Kruttschnitt C., Uggen, C. and Shelton, K. (2000), 'Predictors of Desistance among Sex Offenders: The interaction of Formal and Informal Social Control' Justice Quarterly 17(1): 61-87.

Laub, J.H., Nagin, D. and Sampson, R.J. (1998), 'Trajectories of Change in Criminal Offending: Good Marriages and the Desistance Process', American Sociological Review 63(2): 225-238.

Laub, J. H., and Sampson, R. J. (2001), 'Understanding Desistance from Crime', Crime and Justice, 28: 1-69.

Laws, D.R., and Ward, T. (2011), Desistance from Sex offending: Alternatives to Throwing Away the Keys (New York and London: The Guilford Press).

LeBel, T.P., Burnett, R., Maruna, S. and Bushway, S. (2008), 'The Chicken and Egg of Subjective and Social Factors in Desistance from Crime', European Journal of Criminology 5(2): 131-159.

Liem, M. and Richardson, N. J. (2014), 'The Role of Transformation Narratives in Desistance Among Released Lifers', Criminal Justice and Behavior 41(6): 692-712.

Lussier, P. and Gress, C.L. (2014), 'Community Re-entry and the Path toward Desistance: A Quasi-Experimental Longitudinal Study of Dynamic Factors and Community Risk Management of Adult Sex Offenders', Journal of Criminal Justice 42(2): 111-122.

Lussier P., Tzoumakis S., Cale J., and Amirault J. (2010), 'Criminal Trajectories of Adult Sex Offenders and the Age Effect: Examining the Dynamic Aspect of Offending in Adulthood' International Criminal Justice Review 20(2): 147-168. 
Mann, R.E. (2004), 'Innovations in Sex Offender Treatment', Journal of Sexual Aggression 10(2): 141-152.

Maruna, S. (2001), Making Good: How Ex-offenders Reform and Reclaim Their Lives (Washington: American Psychological Association).

Maruna, S., Lebel, T.P., Mitchell, N. and Naples, M. (2004), 'Pygmalion in the Reintegration Process: Desistance from Crime through the Looking Glass', Psychology, Crime \& Law 10(3): $271-281$.

May, C. (1999), Explaining Reconviction Following A Community Sentence: The Role of Social Factors. Home Office Research Study No. 192 (London: HMSO).

McAdams, D.P. (1993), The Stories We Live By. Personal Myths and the Making of the Self (New York: William Morrow).

-- (2006), 'The Role of Narrative in Personality Psychology Today' Narrative Inquiry 16(1): $11-18$.

McAlinden, A. (2007), The Shaming of Sexual Offenders: Risk, Retribution and Reintegration (Oxford: Hart Publishing)

-- (2009), Employment Opportunities and the Community Reintegration of Sex Offenders. Statistical and Research Series Report No. 20 (Belfast: Northern Ireland Office).

McNeill, F. (2006), 'A Desistance Paradigm for Offender Management', Criminology and Criminal Justice 6(1): 39-62.

McNeill, F., Farrall, S., Lightowler, C., and Maruna, S. (2012), How and Why People Stop Offending: Discovering Desistance. University of Glasgow: Institute for Research and Innovation in Social Services.

Niven, S. and Stewart, D. (2003), Resettlement Outcomes on Release from Prison in 2003. Home Office Research Findings No. 248 (London: Home Office).

Paternoster, R. and Bushway, S. (2009), 'Desistance and the "Feared Self": Toward an 
Identity Theory of Criminal Desistance', The Journal of Criminal Law and Criminology 99(4): 1103-1156.

Presser, L., and S. Sandberg, (2015), 'Narrative Criminology: What's the Story' in L. Presser and S. Sanberg (eds), Narrative Criminology (New York: New York University Press).

Rocque, M, Posick, C. and Paternoster, R. (2016), 'Identities Through Time: An Exploration of Identity Change as a Cause of Desistance', Justice Quarterly 33(1): 45-72.

Sampson R.J. and Laub, J.H. (1993), Crime in the Making: Pathways and Turning Points Through Life (Cambridge, Mass.: Harvard University Press).

-- (2003), 'Life-course Desisters? Trajectories of Crime Among Delinquent Boys Followed to Age 70', Criminology 41(3): 555-592.

Savolainen, J. (2009), 'Work, Family and Criminal Desistance Adult Social Bonds in a Nordic Welfare State', British Journal of Criminology 49(3): 285-304.

Schaefer, B. M., Friedlander, M. L., Blustein, D. L., and Maruna, S. (2004). 'The Work Lives of Child Molesters: A Phenomenological Perspective', Journal of Counseling Psychology 51(2): 226-239.

Scoones, C.D., Willis, G.M. and Grace, R.C. (2012), 'Beyond Static and Dynamic Risk Factors The Incremental Validity of Release Planning for Predicting Sex Offender Recidivism', Journal of Interpersonal Violence 27(2): 222-238.

Serin, R. and Lloyd, C. (2009), 'Examining the Process of Offender Change: The Transition to Crime Desistance', Psychology, Crime and Law 15(4): 347-364.

Seto, M.C. (2008), Pedophilia and Sexual Offending against Children: Theory, Assessment, and Intervention (Washington, DC: American Psychological Association).

Shapland, J., and Bottoms, A. (2011), 'Reflections on Social Values, Offending and Desistance among Young Adult Recidivists', Punishment \& Society 13(3): 256-282.

Smith, J.A., Flowers, P. and Larkin, M. (2009), Interpretative Phenomenological Analysis: 
Theory, Method and Research (London: Sage Publications Ltd).

Soyer, M. (2014), 'The Imagination of Desistance A Juxtaposition of the Construction of Incarceration as a Turning Point and the Reality of Recidivism', British Journal of Criminology 54(1): 91-108.

Uggen, C. (2000), 'Work as a Turning Point in the Life Course of Criminals: A Duration Model of Age, Employment, and Recidivism' American Sociological Review 65: 529546.

Van den Berg, C., Bijleveld, C., Hendriks, J. and Mooi-Reci, I. (2014), 'The Juvenile Sex Offender: The Effect of Employment on Offending, Journal of Criminal Justice 42(2): 145-152.

Vaughan, B. (2007), 'The Internal Narrative of Desistance', British Journal of Criminology 47(3): 390-404.

Ward, T. and Laws, D.R. (2010), 'Desistance from Sex Offending: Motivating Change, Enriching Practice', International Journal of Forensic Mental Health 9(1): 11-23.

Warr, M. (1998), 'Life Course Transitions and Desistance from Crime', Criminology 36(2): 183-216.

-- (2002), Companions in Crime: The Social Aspects of Criminal Conduct (Cambridge: Cambridge University Press).

Weaver, B. (2014), 'Control or Change? Developing Dialogues between Desistance Research and Public Protection Practices', Probation Journal 61(1): 8-26.

Weaver, B., and McNeill, F. (2010), 'Travelling Hopefully: Desistance Theory and Probation Practice', in J. Brayford, F. Cowe and J. Deering (eds), What Else Works?: Creative Work with Offenders (Cullompton: Willan Publishing).

Weinrott, M.R. and Saylor, M. (1991), 'Self-report of Crimes Committed by Sex offenders', Journal of Interpersonal Violence 6(3): 286-300. 
Willis, G.M., Levenson, J.S. and Ward, T. (2010), 'Desistance and Attitudes towards Sex Offenders: Facilitation or Hindrance? Journal of Family Violence 25(6): 545-556.

Wortley, R., and Smallbone, S. (2006), 'Applying Situational Principles to Sexual Offences Against Children', in R.K. Wortley and S.W. Smallbone (eds,) Situational Prevention of Child Sexual Abuse (Devon: Willan Publishing).

-- (2014), 'A Criminal Careers Typology of Child Sexual Abusers', Sexual Abuse: A Journal of Research and Treatment 26(6): 569-585. 